Open Access

\title{
Exploring institutional reform of Korean civil service pension: advocacy coalition framework, policy knowledge and social innovation
}

Keunyoung Lee ${ }^{*}$ id and Kwangho Jung

\author{
* Correspondence: \\ colrok19@snu.ac.kr \\ Korea Institute of Public Affairs, \\ Institute of Information, Knowledge, \\ and Policy, Graduate School of \\ Public Administration, Seoul \\ National University, 1 Gwanak-ro, \\ Gwanak-gu, Seoul, South Korea
}

\begin{abstract}
This paper examines what factors are associated with the 2015 pension reform of Korean civil servant as social innovation. We explore what lessons we can learn from the pension reform in terms of the Advocacy Coalition Framework (ACF) model. The ACF model allows us to identify how the substantial reform is, relying on policy knowledge and entrepreneurs, possible in terms of political and social consensus. It also clearly demonstrates the possibility of systematic pension reform at an appropriate level through social learning and policy learning. Through the ACF model, we review how South Korea's civil servant pension reform act occurred at the end of May 2015. The temporal scope covers from 2009 latest reform, and the 2014's President administrative policy speech that had strongly been showed her will to reform the pension issue to the end of May 2015 when the reform bill enacted. We investigate each advocacy coalition in order to elucidate the actors that constitute the two coalition groups and to scrutinize whether a policy broker had existed in the process. We also attempt to find the relatively stable parameters and external events that affected the reform and also the belief system that shared by two advocacy coalition group. The result clearly shows that the two coalition groups shared their normative beliefs ultimately, for example, the need to change the current civil servant's pension system, but, the gap in the numerical change in the policy core belief and secondary belief between the two actors had seemed to be excessively large and uncompromising. A policy broker who can coordinate the interests and interests of stakeholder groups over the government pension reform proposal was desperately needed. Negotiation and leadership of the policy entrepreneurs led to a settlement of the government pension reform proposal at the end of May 2015. Their entrepreneurial activities led to an appropriate level of social consensus on the sustainable reform of pension system through policy knowledge and learning. Further research is required to explore how models of socially innovative forms of governance are created in various pension reforms across various countries. It is also required to examine how policy entrepreneurs use policy knowledge and information for a successful institutional reform through social innovation across various countries.
\end{abstract}




\section{Introduction}

Knowledge and information are crucial to inducing a grand social consensus on how to define complicated common issues and on how to design reforms to solve them. Knowledge provides policy direction and idea about how to identify and unravel various common issues we face. Social and institutional innovation for global problems and public policy concerns involves heterogeneous interests and competing solutions. It is not easy to find a unified agreeable solution from various political stakeholders, especially not only because of lack of information and knowledge about the resolution but also because of lack of experience to solve them. For instance, it is difficult to design and implement optimal institutional reforms for the public pension, health insurance, and environmental pollutions with social externalities and market failure because of lack of social knowledge about the solution to the reform idea and process as well as a strong political resistance to those reforms.

Various institutional reforms across countries can provide a promising opportunity to learn how social innovation can contribute to reconstructing and harmonizing competing political interests embedded in policy reforms (Dolowitz \& Marsh, 1996, 2000; Greener, 2002; Marier, 2009; Martin, 1995; Peck, 2011; Zahariadis \& Allen, 1995; Weible, 2007). For instance, the evolution and reform of public employee pension systems across countries' pension reform usually involve a very complicated political and economic interests. Since the 1990s, most developed countries have experienced increasing political and social pressures on the need to reform public pensions due to aging and government fiscal deficits. The Korean government has also received increasing political and social pressures on public pension reforms. The past major reforms of civil servant pension in South Korea took place at 1995, 2000, 2009 and 2015. Compared the three previous pension reforms, the 2015 pension reform has resulted in the most cost-cutting policy alternatives through the participation of various stakeholders and political and social consensus processes. The 2015 pension reform in South Korea provides a meaningful social knowledge about how to induce institutional reform involving complicated political interests.

In a real world, it is difficult to find optimal economic and social solution to complicated political issues such as pension reform. There are very few institutional reforms through political consensus and social innovation leading to sustainable pensions system. Most pension reforms across various countries have demonstrated many failures. Some reforms were successful but most of them were not. However, the 2015 pension reform of Korean civil servant is a relatively rare case of successful institutional reform as social innovation. This reform case provides a good insight of how social innovation leads to successful institution reform. There are still few studies about how policy reforms can be explained as a framework of social innovation in terms of policy knowledge, learning, and entrepreneurs in the policy process.

It is surprising that the massive reform of civil servant pension which is hard to imagine in Europe has been achieved through political and social consensus in a short period of time in South Korea. Until now, past reforms of civil servant pension have focused mainly on short-term effects and once the effects of the increase in contributions have disappeared. However, this time, not only did it actually cut pension rates for the first time, but it also freezes pensioners' pensions for five years. In particular, the 5-year freeze of pension is significant because the financial effect of pension reform has a 
positive impact over the long term. The government pension reform proposal has been successfully made with partial sacrifice and concession by public officials. ${ }^{1}$

Park's administration in South Korea is the first government who handled the issue in a wholesale with support from the public. That is why the civil servant pension reform in 2015 shows the uniqueness along the other bills. International pension experts highlight that the civil service pension reform in South Korea is successful and desirable in terms of the current reform process and content. ${ }^{2}$ This pension reform has been regarded as a successful social contract from abroad. It is important to analyze the policy-making process that happens less frequently in society. It is crucial to understand the curiosity of the key policy actors and events for the future government plan that might be repeated.

The composition of this paper is as follows. First, we want to analyze institutional reform such as public servant pension in social innovation and political negotiation process. In particular, we would like to analyze policy processes such as pension reform from the viewpoint of the role of policy negotiators, utilization of policy knowledge, and the learning of civic society on institutional conflicts. Second, we will analyze the reform process of public servant pension based on the model of policy advocacy. Specifically, we would like to focus on the role of policy knowledge and experts. Finally, we emphasize that the solution of the conflicts surrounding the system reform can be analyzed from the viewpoint of policy knowledge and policy community as social innovation.

\section{Institutional reform theories: Social innovation and the ACF model}

Innovation research has expanded its scope and applicability to various open innovation areas including social business and industrial areas (Yun et al., 2016). Recent studies have explored how social innovation can evolve from the medical sector (Roh \& Kim, 2017) and how to implement social innovation (Svirina et al., 2016). Institutional reform and innovation may be significantly related to social business and social innovation. However, little research has attempted to link institutional reform to social innovation in terms of policy coalition framework such as policy entrepreneurs and policy information.

Current complicated society needs smart social innovation for public interest beyond business innovation for profit (Ackerman \& Alstott, 1999; Ayob et al., 2016). Promoting common goods and community values involve sustainable institutional reform to coordinate competing interests from multiple stakeholders. Institutional reform is, however, inherently intertwined with intricate political interests (Christopoulos \& Ingold, 2015; Edmiston, 2016). A typical economic innovation that seeks to maximize utility or profits can hardly lead to appropriate institutional reforms for community sustainability. Social innovation would be essential to solving competing interests involved from various stakeholders through political negotiation and social consensus (Mulgan, 2006). Social innovation allows us to learn how to find cooperative negotiation process and how to generate social knowledge through social interactions among various stakeholders (Mulgan, 2005). Social innovation can provide a social agreement on how multiple competing stakeholders come together to develop new practices that traditionally would have emerged only from a bureaucratic, top-down process in various institutional reforms (Mulgan et al., 2007; Murray et al., 2010). The promising solution of 
an increasingly unequal and social conflict tensions embedded into institutional arrangements and social contract can be derived from social innovation.

\section{Institutional reform as social innovation}

This paper assumes that institutional reforms include policy reform as well as other institutional innovations from rules, norms, and social practices in public policy areas. In this sense, social innovation can include various institutional reforms. Pension reform can be regarded as an institutional reform to adjust and change various eligible rules for pension management. In this paper, pension reform is regarded as policy reform including restructuring and transformation of various rules in pension system. Social innovation in public policy comes from an effective response to the conflict that pits the policy entrepreneur against a hostile political milieu. Social innovation should be viewed in terms of achieving political consensus, even if incomplete reforms are sought rather than in radical changes in pension reform. Further, it is a social innovation for conflict resolution that created social expectation and demand to experience policy learning and future consensus.

Social innovation comes from social experimentation and reshapes power relationships (Manzini, 2014; Mulgan et al., 2007; Nicholls et al., 2015). Social innovation involves social experiences to search for new solutions to unsolved social problems (CajaibaSantana, 2014; Mulgan, 2006). Social innovation seeks to understand the heterogeneous innovation processes that bring about civil-society-based social changes. Social innovation is politically constructed product of a need or a quest for solutions to various community problems. The first process of institutional reform as social innovation is to diffuse and attain recognition of the legitimacy of an innovative project in various policy reforms. The next process is that policy entrepreneurs are to play a positive or negative mediating role to clear up political barriers, to apply diverse information and knowledge embedded into competing interests and conflicts, and to craft and build political consensus.

There have been various types of research on social innovation. However, they have provided an anecdotal evidence and case studies. The topics about social innovation research cover various areas from community innovation, urban development, and social entrepreneurship. This paper focuses on how social innovation can be contributed to explaining the creating of a greater public interest and the common good in policy reforms.

Policy ideas presented by policy experts have created the basic environment for consensus. In the future, we have created social expectations that policy knowledge and experts can play a greater role in addressing conflicts and suggesting solutions.

\section{ACF model: Information, beliefs and policy learning}

Advocacy coalition framework(ACF) describe this political and social process as social innovation to policy transformation for sustainable pension system. ACF and social innovation provide a theoretical framework of the pension reform as political process and social innovation. Relevant stakeholders and political coalitions are involved in the reform process to induce political consensus with common beliefs and agreement. The ACF model describes a useful conceptual framework that explains the stability and 
change of public policies involving various institutional reforms (Jenkins-Smith et al., 1991; Jenkins-Smith \& Sabatier, 1994; Weible, 2007; Weible et al., 2009). It mainly focuses on the coalitions that share normative beliefs and sometimes behave harmoniously. The coalition groups comprehend changes in policy as the results of competition between coalition groups to bring their concepts and beliefs into formal actions. The ACF model is based on the four basic premises.

First, Jenkins-Smith \& Sabatier (1994) claimed that time period of a decade or more should be needed to comprehend the changes in policy process and the role of understanding therein. The concentration on a time period of 10 years or more is originated directly from the findings about the understanding the functions of political studies. An inevitable result is that it is the accumulated effect of findings from different researches and also daily-life-knowledge that has powerful influence on policy (Jenkins-Smith \& Sabatier, 1994). ${ }^{3}$ Second, to understand the policy change over such a time span, Sabatier mentioned that the focus should be onto the policy subsystem's action (1994). ${ }^{4}$ Some scholars argue that, in nowadays society, the most useful analysis unit for learning policy change is not a specific governmental research center. Rather, policy subsystem actors from various places such like both public and private association who are actively worried about policy problems or current matters are more useful unit to understand the policy change. Third, Sabatier claimed that at least for domestic policy, intergovernmental dimension must be contained inside the subsystems (Jenkins-Smith et al., 1991; Weible, 2007; Weible et al., 2009). This is that policy subsystems, most of the time, include actors from all levels of government. To examine policy change only at the national level will, in most instances, be seriously misleading (Mazmanian \& Sabatier, 1989). Lastly, public policies or schemes should be conceptualized as belief systems without a change. The belief system includes such sets of value priorities and certain presumptions about how to achieve them in reality.

Figure 1 summarizes all these four perspectives from ACF. This figure shows three main components of ACF including stable parameters, external events, policy sub systems including coalition group and policy broker. Sabatier explained in his ACF theory that the concept of relatively stable parameters includes the basic values from socio-culture,

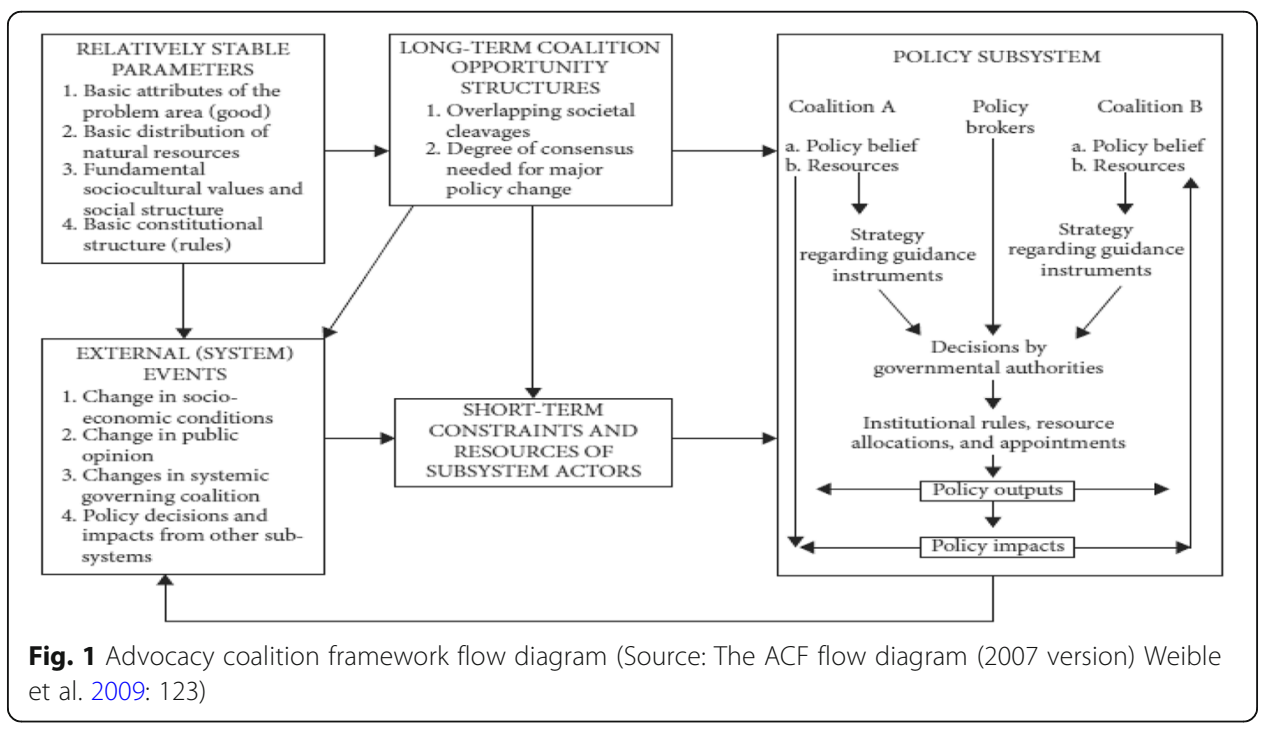


natural resources of political system and constitutional structure (2006). The ACF also provides the critical prerequisite to the major change in political field including major socio-economic alternations(e.g., economic stagnant or the rise of social campaigns), changes in public attitudes, changes in political coalitions including 'crucial' and 'presidential elections'; and policy decisions and influences from other subsystems (Jenkins-Smith \& Sabatier, 1994).

The ACF model provides key concepts to explain policy changes like policy reform as social innovation. The first component is the belief systems of each advocacy coalition (Peffley \& Hurwitz, 1985). Policy core beliefs which symbolize each coalition are causal understandings and basic normative obligations across a whole policy domain or subsystem at the next level. The ACF assumes that policy core beliefs can be described as a fundamental "glue" of coalitions since they stand for basic understandings and practical commitments within the specialized domain of policy brokers or elites. Another belief is a tool for a coalition's belief system to achieve its goals. This belief scheme involves policy priorities regarding worthwhile rules from law or financial allocations, the designs of specific association, and the assessments from a variety of actors' performance. These beliefs are presumed to be more easily adjusted in light of experience, new data or changing strategic analysis and reviews, which may result in institutional reforms to induce social innovation.

The second one is policy coalition to choose one or more policies and strategies that entail the use of 'guidance instruments'. These are, for example, changes in rules, financial reasons, private, or information. Each Coalition considers it as a means of modifying the behavior of various governmental organizations in an effort to become aware of its policy objectives. Normally, conflicting policies and strategies from a variety of coalitions are interceded by a third group of actors, 'policy brokers' as in ACF, whose principal concern is to figure out some reasonable settlements that will decrease and lower the intensity of conflict. The conclusion can be one or more governmental bills or programs, which finally will produce policy outputs at the operational level for like organization permit decisions. These outputs can cause various impacts on targeted matter's parameters (e.g. entitlements or contribution rate), as well as side effects. On the basis of adequate understandings of governmental decisions and the resultant influences, as well as new data and opinions arising from search processes and external dynamics, each advocacy coalition may alter its beliefs, which are generally in the secondary belief, and its political strategies. The latter may involve the seeking of major agency revisions at the collective choice level, more minor corrections at the operational level, or even going outside the subsystem by seeking changes in the dominant coalition at the systemic level (Jenkins-Smith \& Sabatier 1994).

The third one is policy learning to bring on social innovation. Within the overall process of policy change, the advocacy coalition framework has a peculiar interest in policy-oriented learning. Policy-oriented learning refers to behavioral intentions or to relatively enduring alterations of thought. The alternations will result from experience or the new information which are concerned with the modifications or attainment of policy objectives. Policy-oriented learning includes (1) increased information of problem parameters and the factors that affect them, (2) the inside feedback loops described in Fig. 2 regarding policy effectiveness, (3) perceptions concerning external dynamics, and (4) changing understandings and awareness of the probable impacts of other 
substitute policies. The advocacy coalition framework presumes that such learning is a tool that members of a variety of coalitions attempt to understand the world better in order to further their policy objectives. Given that conceptual filtering is a fundamental element of the ACF's model. The individual members from coalition will defy information suggesting their deep core belief or policy core beliefs may be invalid or unattainable and usually will use formal policy analyses to elaborate and support those beliefs or attack their opponents' opinions.

\section{Advocacy coalition framework (ACF) as social learning and social innovation}

\section{Analytical framework}

We apply various policy theories and concepts to explain how to reach the Korean Civil Servant's Pension Reform. Figure 2 shows how policy entrepreneurs and brokers provide policy knowledge and information and then how pension reform plans developed by policy ideas induce political and social consensus as well as policy consensus for the pension reform. All these reform processes involve policy learning as social innovation. More specifically, we use the Advocacy Coalition Framework (ACF) to explain a mechanism to describe the 2015 pension reform process (Jenkins-Smith \& Sabatier, 1994; Weible, 2007). The ACF brings an opportunity to analyze how policy entrepreneurs provide competing solutions and ideas and develop common beliefs through learning process among different advocacy coalitions involved in the pension reform (Mazmanian \& Sabatier, 1989). Another advantage of ACF model allows us to explore how to develop a political, social, and policy consensus regarding the 2015 South Korea's civil servant pension reform act (See Fig. 2).

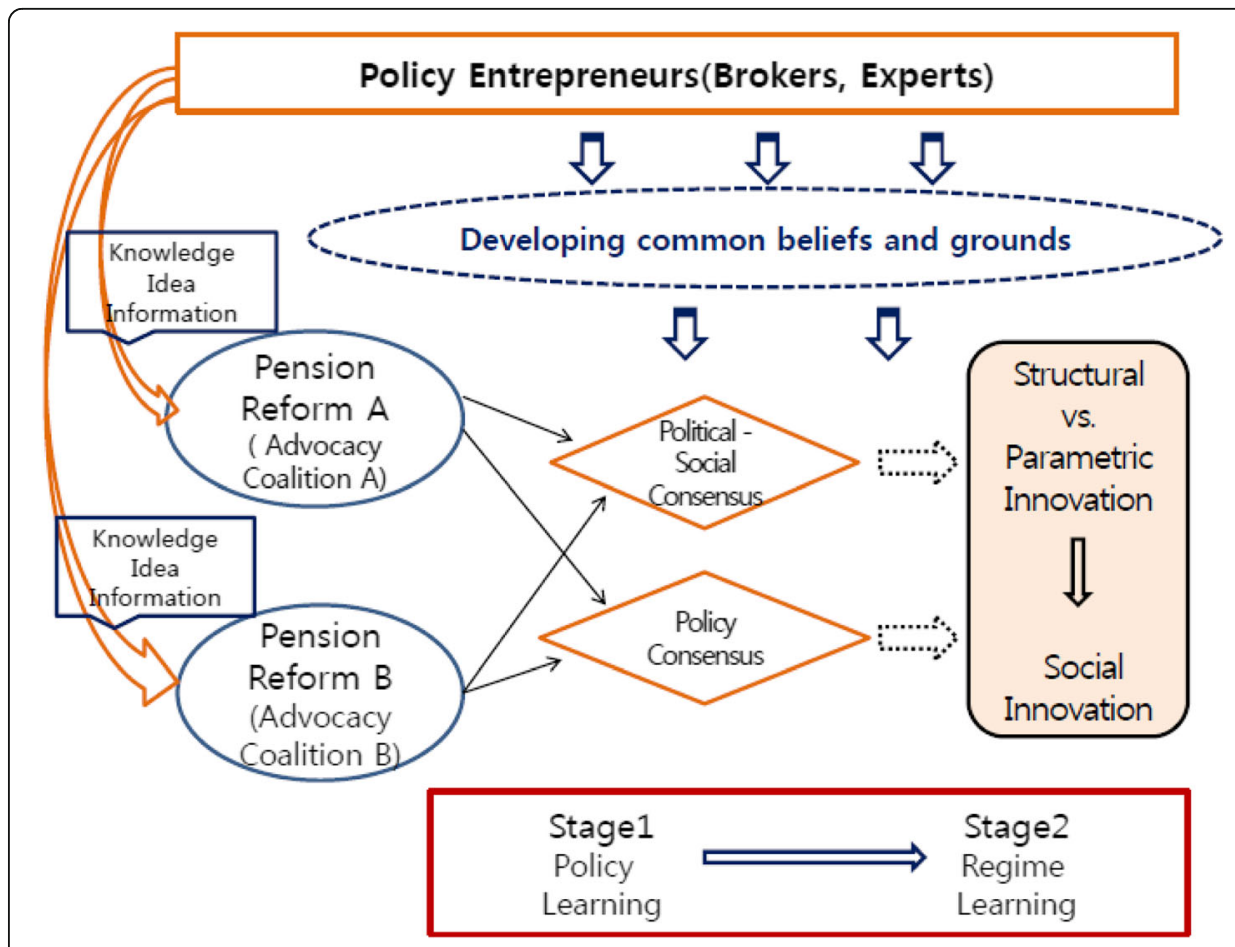

Fig. 2 Graphing the whole process of pension reform as advocacy coalition frame and social innovation 
By using the ACF model, the study will locate the two coalition groups that relates to the pension reform of civil servant in South Korea, understands the relative stable parameter, external events and every detail that made effect on the Korean policy subsystem, and analyze the policy contents, actors and process of the Korean civil servant pension reform that enacted in 2015. In order to do so, the temporal scope of study will cover from the latest reform enacted in 2009 to the end of May 2015 when the new reform bill enacted. First, the study will examine and explain the basic concept of advocacy coalition framework (ACF) and by making use of ACF model; the study will scrutinize the policy-making process of the 2015 pension reform of Korean civil servant.

\section{Analysis of the pension reform of Korean civil servants Historical overview}

President Park Geun-Hye emphasized political parties to support the government's effort in civil servant pension reform. President Park mentioned that "Our future and that of our descendants depend on the ongoing economic reform and national innovation plans" (Bae, 2016) in the New Year's meeting with key executives including the prime minister and head officers from the Saenuri Party which is the major party in South Korea currently. It was unusual for the president to mention the need of reform bill which had been ongoing during New Year's speech. The meeting and speech strongly showed her willingness to reform the civil servant's pension. After the speech, the right-wing party and the experts who intensively claimed about the need of reform had become powerful and carried more weights on their arguments.

On the other hand, amidst a sharp division between the right and left party, the Union strongly expressed their chagrin towards its government about their concerns. According to the interview from chairperson of Korean Government Employees' Union, he mentioned that the need of change is well conceded inside the union society; however, it needs sufficient time and right organization from social agreement to check thoroughly. $\mathrm{He}$ even said that the urgent and clement issue does not mean, "Handle it quickly" (Kim, 2014). Not only from the inside voice, moreover, some scholars were also concerned about the speedy process of the civil servant pension reform due to the president's attention. Kim Jin-Soo, who is an expert in social welfare and professor in Yonsei University, argued that the most important issue in pension reform is the fairness and equity. But, in recent alternative plans, there were no fairness and equity by just cutting the figures and numbers in the book. If the current alternative plan enforces, the plan might threat to the lower level of civil servant's livelihood. Therefore, the country needs sufficient time to improve the structure system completely (Kim, 2014).

Continuing on conflicts between Union and the major party or between scholars, both political parties (e.g., Saenuri and Saechunnyun Parties) rapidly postponed the ongoing extra congress meeting session. It was originally decided for closure on end of May 2015, but delayed by one more day as their debates dragged on. The congress meeting ended months of bipartisan battling over the pension reform. President Park had repeated and pushed on requests for the lines, contents, and compromises of the reform bill aimed for reducing the growing deficits in the civil servant pension fund as in a bid for invigorating the current economic situation. The pension reform bill passed the National Assembly by 233-0 (agree-disagree) with 13 abstentions. After the major 
party (Conservative) and Saechunnyun Party (Progressive) reached a last-minute settlement, the bill that went on the theme of "Pay more, Receive Less" passed through the National Assembly (Jeong, 2015).

Before looking into the reason why the civil servant pension had been reformed, one should understand about the history of civil servant pension in South Korea. In the year of 1992, it was the start of a civilian government in South Korea. Before 1992, there were two military coup-de-tats in South Korea and afterward, it had been the military regime for twenty years in South Korea before 1992. So, in the era of the military government, it was hard for the civil servants to claim and argue on their needs and welfare. Since the basic role and concept of civil servants is to help the citizens and puts the citizens on the top priority, complaining and arguing toward military government, which had strong tendency of centralized government, on their rights was something hard to be realized. Even though the International Labor Organization (ILO) kept warned about the situation in South Korea, the military government had political apathy on the problem. After the civilian government established in 1992, the government finally accept the needs of the union. Basically, the history of South Korea's union of civil servants has been short and the background is unique compared with other countries. From since, in 1998, the officials organized the conference and then continued on appealing their needs of the union to administration during 2004. Then finally, in 2006, with the options of right to organize, right to bargain collectively, but no right to act collectively, they earned the right to make the labor union. The union protected their pension well and the government did not much care about it. However, the government did not forecast the growing financial burden due to the fast-aging population in South Korea. The Ministry of Health and Welfare now predicts that Korean would need to pay an average of $18 \%$ of their earnings on public pension and civil servant pension to fill up a 50\% income replacement rate. However, $9 \%$ of incomes have gone to the public pension and civil servant pension currently (Moon, 2015). Cheong Wa Dae (The Bluehouse) also worried about the problem and publically announced during the New-Year speech. That was why the citizen and the government paid attention to the civil servant pension reform, even though it had not been on the hot seat before the mere modification happened in 2009.

The pension which was enacted for equality brought the inequality towards normal people. A large amount of tax made the indigestible burden for both government and every citizen. The government gave a warning that unless alternation was followed, starting from 2016; the government should have to use 10 billion won in taxpayer's pocket every day to fill up for the financial deficit from the civil servant pension. The atmosphere of needs of change in civil servant's pension emerged not only from the major party (Saenuri), but also from the minor party (Saechunnyun) too. Both parties agreed on changing the segments of the civil servant's pension. However, the exact figures and details for reform bill were the conflicts that dragged the time for two major parties.

Finally, the National Assembly in May 2015 passed the civil servant pension reform bill with the heavy agonizing ordeal from the strength of party conflict(See Table 1 and Table 2). The reform increased the contribution rate of civil servant pension from $7 \%$ to $9 \%$ in the next five years, while decreasing the entitlements from $1.9 \%$ to $1.7 \%$ in phases over 20 years. It also postponed the first payment of civil servant pension by 
Table 1 Past reforms of the Korean civil service pension system

\begin{tabular}{|c|c|}
\hline & Features \\
\hline 1995 Reform & $\begin{array}{l}\text { - Increasing contribution rates }(3.6 \% \rightarrow 4.9 \%) \\
\text { - Introducing the retirement age (age of } 60 \text { only to the newly hired) }\end{array}$ \\
\hline 2000 Reform & $\begin{array}{l}\text { - Increasing contribution rate }(4.9 \% \rightarrow 5.5 \%) \\
\text { - Raising the retirement age of the hired before } 1996 \text { incrementally (will be set } 50 \text { at } \\
2001 \text { and raised } 60 \text { until 2021) } \\
\text { - Expending period of pension calculation (final wage } \rightarrow \text { final } 3 \text { years' average wage) }\end{array}$ \\
\hline 2009 Reform & $\begin{array}{l}\text { - Increasing contribution rates }(5.5 \% \rightarrow 7 \%) \\
\text { - Accrual rates }(2.1 \% \rightarrow 1.9 \%) \\
\text { - Raising the retirement age ( } 65 \text { only to the newly hired) }\end{array}$ \\
\hline 2015 Reform & $\begin{array}{l}\text { - Increasing contribution rates ( } 7 \% \rightarrow 9 \%) \\
\text { - Accrual rates }(1.9 \% \rightarrow 1.7 \%) \\
\text { - Raising the retirement age ( } 65 \text { to all current employees with } 11 \text { years' transition) } \\
\text { ( } 60 \text { only to the newly hired) } \\
\text { - Ceiling of contribution and benefits }(1.8 \text { times of average wage for all } \\
\text { members } \rightarrow 1.6 \text { times) } \\
\text { - Maximum years of contribution( } 33 \text { years } \rightarrow 36 \text { years) } \\
\text { - Pension freezing ( } 5 \text { years from } 2016 \text { to } 2020)\end{array}$ \\
\hline
\end{tabular}

Source: Ministry of Personnel Management (2015)

delaying the retirement age from 60 to 65 years old. Policy report suggests that the big changes to the civil servant pension would cut back the government financial burden about 333 trillion won over the next 70 years.

\section{The background of the $\mathbf{2 0 1 5}$ civil service pension reform}

Until the final pension reform came out, there were important political events. The main Major policy scenes and progress are as follows (See Table 3). On February 14th, 2014, President Park expressed a strong intention for the Civil Service Pension reform. In early 2014, the government commissioned a research institute, Korea Development Institute (KDI), to draft reform proposals and the institute presented its proposals to the government in mid 2014. On October 28th, 2014, the ruling party Saenuri Party (SP) submitted a reform bill in the name of all members. However, civil service unions and the main opposition New Politics Alliance for Democracy (NPAD) strongly opposed the reform bill. In December 29th, 2014, in order to seek a social consensus on the pension reform, the National Assembly set up Special National Assembly Committee and Grand Compromise Committee which comprised rival parties' congressmen, government officials, civil service unions and experts. After having five dozen of conferences over 6 months, in the late May 2015, a grand consensus on the pension reform was reached. On May 29th, 2014, the final reform bill was submitted to the National Assembly and the

Table 2 Comparison between before and after the 2015 pension reform of civil servant

\begin{tabular}{|c|c|c|}
\hline & Before the reform & After the reform \\
\hline - Full suspension & When re-hired & $\begin{array}{l}\text { when re-hired, or when employed under } \\
\text { public corporate, or when extended to } \\
\text { elective civil servants }\end{array}$ \\
\hline - Partial suspension (Reference) & $\begin{array}{l}\text { Average salary (3380 thousand } \\
\text { won) }\end{array}$ & Average pension (2240 thousand won) \\
\hline - Coverage & Real estate income excluded & Real estate income included \\
\hline - Indexation & CPI & CPI after 5 years' pension freezing \\
\hline
\end{tabular}

Source: Ministry of Personnel Management (2015) 
Table 3 Key policy events and aspects in the 2015 pension reform

\begin{tabular}{ll}
\hline Date & Events \\
\hline February 25th, 2014 & $\begin{array}{l}\text { - President Park expressed a strong intension for the Civil Service Pension reform } \\
\text { in her annual announcement }\end{array}$ \\
January June, 2014 & $\begin{array}{l}\text { - Korea Development Institute (KDI) carried out a reform project } \\
\text { - The government (the Ministry of Personnel Management) announced her } \\
\text { reform proposal }\end{array}$ \\
October 17th, 2014 & - The ruling Saenuri Party(SP) submitted a Civil Service Pension reform bill \\
October 28th, 2014 & - The National Assembly set up the Special Committee and the Grand Compromise \\
December 29th, 2014 & Committee \\
January May, 2014 & The Special Committee in the National Assembly, coupled with the Grand \\
& - About 59 times of committee conferences and public hearings (90 times when \\
unofficial meetings are included) & - The National Assembly agreed on the reform bill in a wider context \\
May 2nd, 2015 & The National Assembly passed the Civil Service Pension Reform bill \\
May 29th, 2015 & - The Korean government made the law public \\
June 22th, 2015 & - The Reform bill will be implemented. \\
January 1st, 2016 & Mangement (2015)
\end{tabular}

Source: Ministry of Personnel Management (2015)

bill passed 233-0 with 13 abstentions. On June 22th, 2015, the government made the law public and the law will be implemented from January 1st, 2016. In overall, both of the government and the National Assembly and opened a way to resolve various reform problems through social compromise and consensus.

Through these institutional processes, the government and the ruling party sought to establish consensus through several rounds of talks with civil service organizations. In December 2014, the ruling party and the opposition party launched a 'Grand Consensus Summit(GSC)' to discuss public employee pension reform proposals. The opposition party members, opposition lawmakers, experts, government representatives, civic groups, and public service organizations participated in the GCS. This institutional mechanism has led to a consensus on the reform schemes of income redistribution and the efficiency of pension financing, which had not been tried in the past to reform civil servant pensions.

The 2015 South Korea civil servant pension reform is the case of confrontation between the 'structure reform coalition group (the Government and the Saenuri party)' that shares the same belief system of improving the current civil servant pension system into complete structure change and the 'parametric-reform coalition group (the opposition party, Federation of Government Employee Union, The Korean Government Employees' Union)' that shares the belief system of adhering the current situation or at least adjusting the figures. Using the advocacy coalition framework, the study will analyze the policymaking process of civil servant pension in South Korea that happened in 2015.

To use ACF model, the civil servant pension reform has to meet four premises. First, the time period of 10 years or more should be needed to comprehend the changes in policy process. Before looking into the first premise, in the United States, the presidency acknowledges the reappointment, therefore, the process of policy change can prolong over decade or more. However, the presidency in South Korea does not accept the reappointment, therefore, the first premise of ACF does not fit the certain case in South Korea. Thus, to adjust the theory to the situation in South Korea, the 
process of policy change requires a time perspective of five years or more. It had been 20 years after the first amendment of civil servant pension was made (See Table 4). All the four amendments were adjusted to increase the contribution rate and to diminish the entitlements. The table below is the changes in contribution rate and entitlement figures of civil servant pension during the last 20 years.

Second and third, to understand the policy change over such a time span, ACF presumed that the focus should be onto the policy subsystem's action. For example, inside the policy subsystems, there are interactions between actors from various institutions and coalitions that try to seek, follow or influence the governmental decisions in a political field. Also, subsystems should contain an intergovernmental dimension, at least for domestic policy. There had been many changes in Korean political parties and presidency. The interaction of actors and governmental decision were changed in many ways during the time especially between the Second Amendment (The major party was considerably progressive than the opposite party) and Third Amendment (The major part was considerably conservative than the opposite party). Also, the two formal presidents during the second and before third were elected from the progressive party. The fourth amendment has its uniqueness in the interaction of actors because the current administration is the first government that re-elected from the conservative party.

Fourth, public policies or schemes should be conceptualized as belief systems without a change. The importance of the fourth premise that public policies and programs are blended theories about how to achieve their objectives. Each coalition that aggregated due to the civil servant pension reform had conceptualized their belief system into policy plans and carried through over time.

\section{External events in civil servant pension reform}

\section{The attitude change in public \& major socio-economic changes}

The global financial crisis of 2007 to 2009 was the most serious meltdown to shake the global economies in more than 70 years. As it emerged and got into a shape, it confounded governments, financial institutions, markets and industries, academics, media commentators and finally the attitudes of the public. In a matter of months and years, the speed of the crisis and its unexpected twists and turns excited fears around the world. The crisis swept around the globe, impacting on financial markets, economies and inevitably government budgets like tax problems. The crisis changed taxpayers' attitudes towards civil servants and its pension. In South Korea, there is even nickname for civil servants - "The Thick Iron Rice-Cooker", which means they secured their job and livelihood for good. The public acknowledged that the current law for civil servant pension act is compensation for their generally low salaries. However, the statement

Table 4 The history of civil servant pension in South Korea

\begin{tabular}{llll}
\hline Time & Content & Contribution Rate & Entitlements \\
\hline 1982 & Civil Servant's Pension Act & $3.6 \%$ & $2.1 \%$ \\
1995 & First Amendment & $4.9 \%$ & $2.1 \%$ \\
2000 & Second Amendment & $5.5 \%$ & $2.1 \%$ \\
2009 & Third Amendment & $7.0 \%$ & $1.9 \%$ \\
2015 & Fourth Amendment & $9.0 \%$ & $1.7 \%$ \\
\hline
\end{tabular}


also seems to be outdated for the public opinion, given that civil servant's paychecks fall short of those among large companies, but are above the average in the private sector like small and medium-sized enterprises.

According to a Gallup poll conducted from April 28 to 30 in the year of 2015, involving 1005 adults who can vote, $57 \%$ of respondents said they approved the revision of the act, while $25 \%$ opposed the revision, well within the margin of error of plus or minus 3.1 percentage points (2015). Gallup analyzed that, "the younger generation showed the hostility and antagonism toward current act since the generation has a lot of job applicants relatively". Also, in the Gallup poll, the question asking, "When is the right moment for the passing the bill?" $60 \%$ of people responded, "As soon as possible" (Gallup Korea Daily Opinion, 2015).

\section{Changes in the systemic governing coalition}

The government and Congress in South Korea had delayed addressing the issue of pensions for civil servants, despite being aware of decades that the 2009's civil servant pension plan is not affordable. However, there had been changes in the political history of modern Korea. After the 2009 presidential election, it marked a structural shift in the political history of modern Korea, indicating the triumphant ascension of the conservatives after ten years of exile. The former President Lee Myung-Bak and his government stepped in and tried to amend the civil servant pension. He strengthened the basis for the reform bill in 2009 however it was evaluated as mere revolution since there was no help from the public or congress and administration itself put less priority onto the problem. After his period had ended, another victory went to the conservative party again in the 2013 presidential election. The current President Park Geun-Hye administration had spurred and accelerated to reform the civil servant pension. President Park Geun-hye called for efforts to ensure a bill meant to reform the pension system for civil servants will pass the parliament by the end of 2014. President Park addressed that, "We will pass onto our future generations a big burden that will not be bearable and deal a devastating blow to the state finances ... if the reform is delayed again," in a Cabinet meeting ("Park Calls..." 2014). President Park made the case for civil servant pension reform, addressing it would be a difficult and painful process but would only get worse if postponed further. In the year of 2015, the presidential office urged for the swift passage of a controversial bill to reform the civil servant pension system as the National Assembly is slated to open an extra session within the first quarter of 2015. The bill to re-structure the debt-ridden civil servant pension plan had been the top priority of the Park Geun-hye government in 2015 .

\section{Policy subsystem - coalition group in civil servant pension reform}

\section{Advocacy coalition group}

Under the circumstance that was affected by various external effects, there were a series of subsystem actors who had constructed the coalition groups for civil servant pension reform - 'structure reform' or 'parametric reform'. Before the reform in 2015, only rare amounts of scholars and politicians were taking the civil servants pension seriously. Since the civil servants played and still play important role in the election, it was not easy and comfortable for politicians to take up a scalpel to perform the operation 
which might lead to losing the supporters and votes. However, after suffering from the stagnant economy, the government financial deficit stood out conspicuously. The tax began to be the burden for the public and the civil servant pension which was paid by tax developed into the pain in the neck. This lead the candidate from the conservative party won the presidential election both in 2009 and 2013. Also, many of scholars had continued to warn the urgent situation about the civil servant pension and the public's attention started to focus on the matter of civil servant pension.

The civil servant pension reform was the process of the conflicts and the compromises between two advocacy coalition groups - one who wanted a rapid structural change of the civil servant pension and the other who did not agree on the rapid change. It is true that the left-wing party agreed on reforming the civil servant pension. However, both the left-wing party and the Korean Government Employees' Union were not satisfied with the radical change that did not think much for the civil servants, but only wants unconditional consent from the left-wing party and the Union. From their belief system, the advocacy coalition group had been formed. In the 'structure reform coalition group', there were the Korean government (Ministry of Personnel Management) and the Major Party (Saenuri Party). On the other sides, the 'parametric reform coalition group' had been established. In the group, there were the Opposition Party (Saechunnyun Party), Korean Government Employees' Union, and Federation of Government Employee Unions (Fig. 3).

\section{The belief system}

Based on their belief system, both advocacy coalition groups struggle to fulfill their goals to be made into a policy. Each actor shares their belief system and unites into an advocacy coalition group. The belief system is the key principle that connects and bonds the advocacy coalition group and the group shares the same belief systems (Haas, 1990; Weible et al., 2009). In the belief system, the hierarchy structure - deep core belief, policy core belief, and secondary belief - were formed inside. Policy knowledge becomes power and distinguishes the positions of different political groups embedded into policy reform process (Haas, 1990).

In the case of the deep core belief, both advocacy coalition groups ('structure reform coalition group' and 'parametric reform coalition group') acknowledged the characteristic of basic problems in the civil servant pension. The increase of pension receiver brought the government financial deficit in pension and comparing with the public pension, the unfairness of civil servant pension benefit had been visualized by both advocacy coalition groups.

\begin{tabular}{|c|c|}
\hline \multicolumn{1}{|c|}{$<$ Rapid } & \multicolumn{1}{c|}{$<$ Incremental } \\
Parametric Reform $>$ \\
Structure Reform $>$ \\
- Ministry of Personnel \\
Management (Government) \\
- Saenuri Party (Ruling Party)
\end{tabular}


However, in the case of the policy core belief, the two sides showed a different point of stances. The government and the right-wing party wanted the civil servant pension to be changed into complete structure reform. The 'structure reform coalition group' assumed that even though the 2009 civil servant pension reform had been made, they thought that the 2009 reform still cannot meet the demand of the future budget. Therefore, the group brought out the idea that not only adjusting the figures, but they wanted the complete structural change in the pension bill. The group claimed that the current tenure civil servants should do, 'pay more and receive less in the future', and the pension for the newly designated civil servants should be included to the public pension same with all the other citizens. On the other hand, the left-wing party, Federation of Government Employee Unions, and Korean Government Employees' Union could not agree on these changes. Especially, Korean Government Employees' Union, which is the organization that exists outside the law boundary but still powerful in the field, did not want to change or reform the bill at all. The union remained the same stance from the start to the end. From its statement, Korean Government Employees' Union insisted that the reform will be the change for the worse and it will be the retrogressive revision in the future. The union even used the word, "Employee Bashing" in its statement (Korean Government Employee' Union 2015). But, the left-wing party and the Federation of Government Employee Union, which is legally acknowledged as a union, agreed on changing the civil servant pension. They claimed that the civil servant pension should not be transferred into the public pension, and the pension only should need the changes in the figures from the current bill. The differences in the policy deep core, of course, developed into the difference in the secondary beliefs.

In the case of secondary belief, 'structure reform coalition group' insisted the "Complete Structure Reform". Inside the complete structure reform, the main purpose was that the civil servant pension should eventually transfer into the public pension in order to reduce the current debt in the government financial plan. Therefore, the 2015 reform should be the first step for terminating the civil servant pension. On the other sides, 'parametric reform coalition group' proclaimed the "Parametric Reform". In the parametric reform proposal, the group claimed that to reduce the deficit, the figures of contribution rate and entitlements should be adjusted, not the whole civil servant system. Since the civil servant pension contributes to the stability of the lives of civil servants, transferring the civil servant pension into the public pension is the preposterous reform that does not consider the civil servant's side.

\section{Roles of policy entrepreneurs}

\section{Policy experts as both entrepreneurs and brokers}

Conflicting strategies from a variety of coalitions are normally mediated by a third group of actors, ACF used the term, 'policy brokers' or 'policy entrepreneurs' whose principal care is to find some reasonable conditions that will reduce intense conflict with a neutral position (Christopoulos \& Ingold, 2015; Jenkins-Smith \& Sabatier 1994; Rich, 2005; Smith, 1993). In this case, there were two policy entrepreneurs: Kim Tae-il (Professor of Public Administration at Korea University) and Kim Yong-Ha (Professor of Finance and Insurance at Soonchunhyang University). Since the two coalition groups could not get agreed on any of their proposals, the two policy brokers from third-party stepped-in and made the compromises (Table 5). 


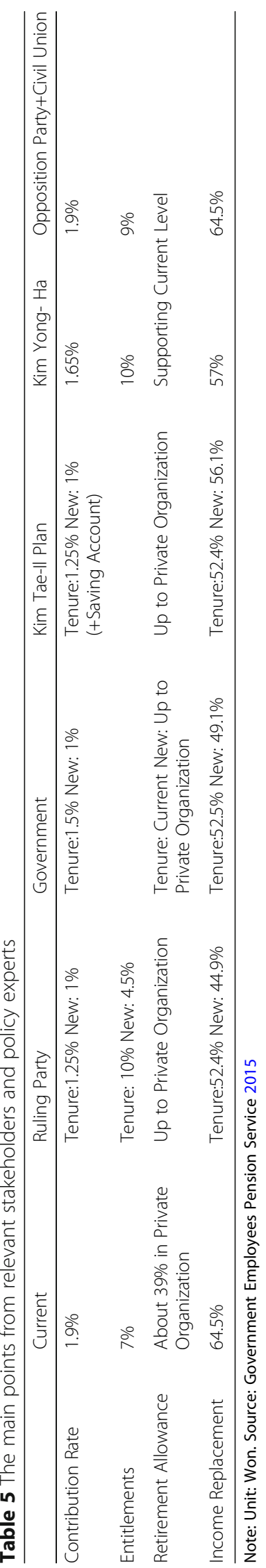


The main point of the Kim Tae-Il plan was to have a saving account as an arbitration scheme. In the long run, the civil servant pension should be merged with the National Pension System as the second pillar of the multi-pillar system. The figures he made were much same with the government proposal, however, he insisted a deal in conjunction with the new individual retirement account to preserve the reduction amount in contribution rate and entitlements. The government will compensate the amount of reduction. By doing it so, it will make easier to merge the civil servant pension into the National Pension System in the future. However, the Opposition Party and the Civil Servant's Union did not agree to the proposal. They addressed that: 1 . they worry about the gradual decrease in government compensation for civil servants as time goes by. 2 . they worry about the role of National Pension in the future because the pension might gradually decrease as well.

After the two coalition groups rejected several proposals such like government plan, both party plans, and Professor Kim Tae-Il plan, the last proposal from Professor Kim Yong-Ha had been started to take the center stage. The plan made by Kim Yong-ha, who is a financial management Professor at Soonchunhyang University offers the same payment and premium ratios of $1.65 \%$ and $10.0 \%$, respectively, to both newly hired and existing civil servant. It suggested raising the premium ratio by 3 percentage points from $7.0 \%$ while lowering the current payment ratio of $1.9 \%$ by 0.25 percentage point. Prof. Kim Yong-Ha had the highest amount of savings as high as 394.5 trillion won until the year of 2085 (Kang, 2015) (Table 6).

\section{Political consensus}

After months of tough struggling, the major and opposition parties passed a bill on May 2015 to modify the pension plan for civil servants. The parties had to extend the extra congress session, originally decided to close on the day before, by one more day as their negotiations dragged on. During the period, Cho Yun-Sun who is Senior Secretary to the President for Political Affairs expressed her intention to resign because of delaying the reform. At last, the main point of the bill went as civil servants to pay more now and receive less in the future. Specifically, the modified plan compels them to contribute $9 \%$ of their monthly income to their pension plan, raising the rate from the current $7 \%$ over the next five years, while reducing their pension payment rate to $1.7 \%$ from $1.9 \%$ over the next twenty years. With the passage of the pension reform bill, the government will be able to secure about 333 trillion won over the next 70 years. It is true that the reformed bill did not follow perfectly on the proposal that the policy brokers made. However, it is also true that the policy brokers found some reasonable compromises that will lessen the intense conflict between two coalition groups (Ministry of Security and Administration and civil unions). From the reformed bill, one can see that in order to conduct and adjust the conflict between the advocacy coalition groups, the existence of policy broker can play a major role to produce the successful policy outcome.

\section{Conclusion and implications}

\section{Summary}

This case study provides a theoretical framework about how policy knowledge and entrepreneurs can contribute to building institutional reform as social innovation. We examined how pension reform plans developed by policy entrepreneurs(experts or 


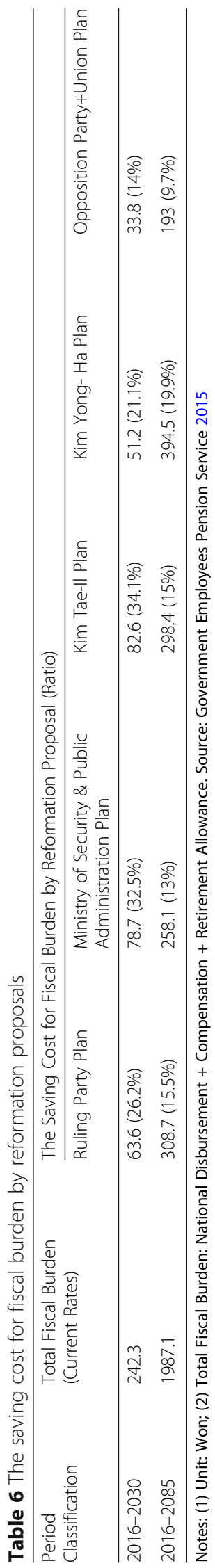


brokers) can induce a political consensus to the pension reform. Table 7 shows a payoff matrix between two different advocacy coalition groups toward the 2015 pension reform proposals. The coalition A group supported by the union groups and minority political party(opposition party) disagrees with the reform because the reform cut the pension benefits. In this sense, the reform generates a negative pay-off matrix(e.g. - 3) for the coalition A group but nothing more payment (e.g., 0) without reform. On the other hand, the coalition B group supports the reform to design a sustainable financial pension scheme. However, a pay-off matrix may be not positive(e.g., 0) for the coalition $B$ group because the reform involves a huge political resistance and the payoff matrix is even worse(e.g., - 3) without reform for this coalition B group.

Based on the nature of the pay-off matrix, the optimal strategy is Output3, where the coalition A group disagree on the reform and the coalition B group agree on it. In other words, Output3 means we cannot develop a political consensus for the pension reform. The reform consensus is possible at only Output 4. However, the coalition A disagree on Output 4 because this group does not want to reform. What factors can build the reform consensus by relocating from Output 3 to Output 4. Policy knowledge generates political pressure that pushes the coalition A group into agree the pension reform and policy entrepreneurs also persuaded the coalition A group into accepting the reform proposal. Policy entrepreneurs explored a common ground that both coalition groups can agree on, where the pension reform proposal involved the parametric reform. The pension reform process can be regarded as social innovation allowing political consensus with competing political interests and providing a learning opportunity of social learning that Korean society.

\section{Policy implications and further research}

The ACF model provides social implications about how to induce significant policy reform through constructing common values and beliefs. More specifically, this case suggests that policy knowledge and information about pension reform proposals can play a key role in preventing stakeholder groups from leaving the line of the pension reform. A detailed roadmap for specific policy alternatives and pension reform proposals was specifically reported in the media, creating an atmosphere for social consensus (Radaelli, 1995). Specific information or policy knowledge on institutional reforms from relevant stakeholders has put pressure on social consensus. In particular, if information and knowledge on specific pension reform proposals were not provided to the public through policy experts with diverse stances from online mass media, resistance

Table 7 Pay off matrix of building political consensus for the 2015 pension reform of Korean civil servants

\begin{tabular}{llll}
\hline & \multicolumn{2}{l}{$\begin{array}{l}\text { Advocacy Coalition A (Disagree on Reform: } \\
\text { Minority Party, Union) }\end{array}$} \\
\cline { 3 - 4 } & & No & Yes \\
\hline Advocacy Coalition B (Agree on Reform: & No & Output 1 & Output 2 \\
Majority (Ruling) Party, Blue House) & & (No-No) & (Yes-No) \\
& & $(0-3)$ & $-3-3$ \\
& Yes & Output 3 & Output 4 \\
& & $($ No-Yes) & (Yes-Yes) \\
& & $(00)$ & $(-3,0)$ \\
\hline
\end{tabular}


from public employee unions' pension reform would be strong. The presentation of alternatives to the pension reform proposals from the Korean Pension Association as well as policy experts involved in the ruling party and the opposition party prompted national consensus on the necessity and necessity of reforming the public employee pension system. Specific and clear information may prevent seeking to blame games for competing solutions to massive institutional reforms (Weaver, 2010).

Due to the increasing social pressure on civil unions, civil unions have accepted pension reforms. Social innovation is achieved through the pressure on stakeholders to draw concessions and sacrifices. The appropriate level of civic responsibility and pressure for stakeholders surrounding pension reform is an effective factor in eliminating the obstacles to complex pension reforms. In addition, stakeholders involved in pension reform learn from civic responsibilities to reduce social conflicts, providing fundamental assets of sustainable social innovation. In summary, policy knowledge about specific concrete policy alternatives to pension reforms has put a great deal of social pressures on the government to restrain the resistance of civil unions and to encourage social consensus on reform proposals. In addition, the government and the ruling party had a strong push for President Park's will - public sector reform. In the Public Sector Reform Program under the Park Administration of South Korea, reform of the public pension system was set as the most important priority. These government-led strong reform initiatives played a fundamental role in the pension reform proposal. In addition, policy entrepreneurs attempted to build a strong link between positive government intervention and policy knowledge. These factors contributed to inducing a political consensus to the pension reform proposal. Further, this policy experience and learning to achieve political consensus to pension reform with competing interests in South Korea will provide social asset to facilitate future institutional reforms as social innovation.

The study still shows some limitations in using the ACF model to the 2015 South Korea civil servant pension reform. First, as mentioned early that one of the ACF model's premise is based on the 10 years administration period. Unlike from the United States or other countries that usually last decade for the presidential period, the administration in South Korea only activates 4 years. Second, as most of the references are based on the news, statements, and speech, it was hard to know the changes in the attitudes of each actor or the process of progress during the meeting thoroughly. Future research is required to interview each actor and find out how and why they changed their stances and positions. In addition, it is necessary to study social knowledge and experience about how political consensus on various social conflicts and policy agenda are formed and what civic learning and skills are useful for the reform process (Stone, 2001, 2002). Finally, we need a better theory to explain how knowledge and ideas can contribute to solving various political and social dilemmas embedded into public and social agenda for community innovation(Bekkers et al., 2013; Béland, 2005). Future research is required to examine various successful or unsuccessful policy reforms derived from policy ideas and knowledge.

\section{Endnotes}

${ }^{1}$ The contribution and burden ratio of the public employee pension law is raised from $14 \%$ to $18 \%$, the pension payment rate is reduced from $1.9 \%$ to $1.7 \%$, and the survivor pension benefit rate is $60 \%$ from $70 \%$ Respectively. The pension age will be adjusted 
gradually from the current age of 60 to 65 and the retirement pension and survivor pension amount will be frozen regardless of the price level for five years from 2016. The pension reform of Korean civil servants came into effect from January 1, 2016 and would be expected to reduce approximately the amount of 1.5 trillion won in 2016 and 497 trillion won within 70 years in the future.

${ }^{2}$ Bernd Marin, director of the Austrian Institute for Social Welfare Policy, said it was a tremendous success for Korea to make pension reforms in a relatively short period of time, which is difficult to draw social consensus in the short term in Europe. In addition, Hashimann, a director of pension bureau, who works for the Austrian prime minister, said, "The $4 \%$ increase in contributions made by Korean officials and the Korean government through the reform over the past four years is a courageous choice in the world." He also mentioned, "It is desirable to downgrade the annual pension rate gradually from $1.9 \%$ to $1.7 \%$ over 20 years." Junichiro Sakamoto at Nomura Research Institute of Japan also ranked South Korea's civil service pension reform as a great success.

${ }^{3}$ For instance, Weiss \& Bucuvalas (1977) argued that a concentration below 10 or less years on policy decision-making eventually will underestimate the influence of policy analysis because certain study or works are made primarily to modify the perceptual systems of policy establishers over time. For example, the literature writings or great works on policy tools also shows to the need for time frames of 10 years or more, to finish at least one implementation or reformulation cycle and to gain and acquire a reasonably accurate picture of success and failure. Many of studies have described that enterprising plans or schemes that appeared after several years to be mean failures gained more favorable scores in assessments when considered in a longer time period, initial successes may be vaporized over time vice versa (Sabatier \& Jenkins-Smith, 1994).

${ }^{4}$ For example, inside the policy subsystems, there are interactions between actors from various institutions and coalitions that try to seek, follow or influence the governmental decisions in a political field. Scholz insisted that the concept and image of policy subsystems should be expended from traditional view of iron triangles limited to single level of government such as political associations, legislative committees, or interest groups to more profound levels such like actors from various government positions, as well as press, policy analysts or reporter who play important roles in the creation, dissemination, and criteria of policy plans (Scholz, 1991).

\section{Acknowledgements}

All the members of SOltmC conference listed below contributed to the design of the study and this manuscript and all have approved the manuscript's content.

Chan-woo Kim (GSPA, Seoul National University), John Yi (Saint Joseph's University, USA), Deborah Dougherty (Rutgers University), Seung-Hee Lee (Southern Illinois University, USA).

\section{Funding}

Not applicable. No funding was received.

Availability of data and materials

Not applicable. This manuscript does not contain any data set.

Authors' contributions

$\mathrm{KL}$ has written this manuscript. KJ has managed the structure of manuscript and the terms that used in manuscript.

Both authors read and approved the final manuscript. 


\section{Publisher's Note}

Springer Nature remains neutral with regard to jurisdictional claims in published maps and institutional affiliations.

\section{Received: 22 January 2018 Accepted: 19 February 2018}

Published online: 28 April 2018

\section{References}

Ackerman, B.A, \& Alstott, A. (1999). The stakeholder society. New Haven: Yale University Press.

Ayob, N., Teasdale, S., \& Fagan, K. (2016). How social innovation 'came to be': Tracing the evolution of a contested concept. Journal of Social Policy, 45(4), 635-653.

Bae, H. (2016). Park pushes parties for reform. The Korea Herald. Retrieved January 13, 2016, from http://www. koreaherald.com/view.php?ud=20160104001082

Bekkers, V. J. J. M., Tummers, L. G., \& Voorberg, W. H. (2013). From public innovation to social innovation in the public sector: A literature review of relevant drivers and barriers. Rotterdam: Erasmus University Rotterdam.

Béland, D. (2005). Ideas and social policy: An institutionalist perspective. Social Policy \& Administration, 39(1), 1-18.

Cajaiba-Santana, G. (2014). Social innovation: Moving the field forward. A conceptual framework. Technological Forecasting and Social Change, 82, 42-51.

Christopoulos, D., \& Ingold, K. (2015). Exceptional or just well connected? Political entrepreneurs and brokers in policy making. European Political Science Review, 7(3), 475-498.

Dolowitz, D., \& Marsh, D. (1996). Who learns from whom: A review of the policy transfer literature. Political Studies, $44,343-357$.

Dolowitz, D. P., \& Marsh, D. (2000). Learning from abroad: The role of policy transfer in contemporary policy-making. Governance, 13(1), 5-23.

Edmiston, D. (2016). The (A) politics of social innovation policy in Europe: Implications for Sociostructural change and power relations (no. 32). CrESSI working papers.

Gallup Korea Daily Opinion (Rep. No. 160). (2015) Retrieved August 12, 2015, from Gallup Korea website: http://www. gallup.co.kr/gallupdb/reportContent.asp?seqNo=652

Government Employees Pension Service, Government Employees Pension Reform. (2015) The main points by each reformation proposals [Press release]. Retrieved December 30, 2015.

Greener, I. (2002). Understanding NHS reform: The policy-transfer, social learning, and path-dependency perspectives. Governance, 15(2), 161-183.

Haas, E. B. (1990). When knowledge is power: Three models of change in international organizations (Vol.22). Berkeley: University of California Press.

Jenkins-Smith, H. C., St. Clair, G. K., \& Woods, B. (1991). Explaining change in policy subsystems: Analysis of coalition stability and defection over time. American Journal of Political Science, 851-880.

Jenkins-Smith, H. C., \& Sabatier, P. A. (1994). Evaluating the advocacy coalition framework. Journal of Public Policy, 14, $175-175$.

Jeong, H. (2015). Civil service pension reform, 60 other bills pass assembly. In The Korea herald Retrieved January 10, 2016, from http://www.koreaherald.com/view.php?ud=20150529000700.

Kang, K. (2015). Gov't releases analysis results on competing public employees pension reform plans. In The Korean economic daily Retrieved January 04, 2016, from http://english.hankyung.com/news/apps/news.view?c1=01\&nkey= 201504102215061.

Kim, J. (2014). Civil servant pension reform, the position of union and the Expert. Asia Today Retrieved January 13, 2016, from http://www.asiatoday.co.kr/view.php?key=20141203010002218.

Korean Government Employee' Union. (2015) The Position of Korean Government Employee' Union on Civil Servant Pension Reform [Press release]. Retrieved March 30, 2015, from http://kgeu.org/board/view.asp?blD= Ncomment\&umber=37015

Manzini, E. (2014). Making things happen: Social innovation and design. Design Issues, 30(1), 57-66.

Marier, P. (2009). The power of institutionalized learning: The uses and practices of commissions to generate policy change. Journal of European Public Policy, 16(8), 1204-1223.

Martin, C. J. (1995). Nature or nurture? Sources of firm preference for national health reform. American Political Science Review, 89(4), 898-913.

Mazmanian, D. \& Sabatier, P. (1989) Implementation and public policy with a new postscript.

Ministry of Personnel Management. (2015) 2015 Korean Civil Service Pension Reform. August, 2015.

Moon, H. (2015). Expanding coverage of the National Pension in Korea: the effectiveness of the matching contribution subsidy (pp. 137-162). Edward Elgar Publishing.

Mulgan, G. (2005). Government and knowledge. Evidence and Policy Journal, 1(2), 215-226.

Mulgan, G. (2006). The process of social innovation. Innovations, 1(2), 145-162.

Mulgan, G., Tucker, S., Ali, R., \& Sanders, B. (2007) Social innovation: what it is, why it matters and how it can be accelerated. London: Young Foundation.

Murray, R., Caulier-Grice, J., \& Mulgan, G. (2010). The open book of social innovation. London: National endowment for science, technology and the art.

Nicholls, A., Simon, J., \& Gabriel, M. (2015). Introduction: Dimensions of social innovation. In New Frontiers in Social Innovation Research (pp. 1-26). UK: Palgrave Macmillan.

Peck, J. (2011). Geographies of policy: From transfer-diffusion to mobility-mutation. Progress in Human Geography, 35(6), 773-797.

Peffley, M. A., \& Hurwitz, J. (1985). A hierarchical model of attitude constraint. American Journal of Political Science, 29(4), 871-890

Radaelli, C. M. (1995). The role of knowledge in the policy process. Journal of European Public Policy, 2(2), 159-183.

Rich, A. (2005). Think tanks, public policy, and the politics of expertise. Cambridge: Cambridge University Press. 
Roh, C. Y., \& Kim, S. (2017). Medical innovation and social externality. Journal of open innovation: Technology, market, and complexity, 3(1), 3.

Scholz, J. T. (1991). Cooperative regulatory enforcement and the politics of administrative effectiveness. American Political Science Review, 85(1), 115-136.

Smith, J. A. (1993). The idea brokers: think tanks and the rise of the new policy elite. New York: Free Press.

Stone, D. (2001). Think tanks, global lesson-drawing and networking social policy ideas. Global Social Policy, 1(3), 338-360.

Stone, D. (2002). Using knowledge: The dilemmas of bridging research and policy. Compare: A Journal of Comparative and International Education, 32(3), 285-296.

Svirina, A., Zabbarova, A., \& Oganisjana, K. (2016). Implementing open innovation concept in social business. Journal of open innovation: Technology, market, and Complexity, 2(1), 20.

Weaver, R. K. (2010). Automatic government: The politics of indexation. Brookings Institution Press.

Weible, C. (2007). An advocacy coalition framework approach to stakeholder analysis: Understanding the political context of California marine protected area policy. Journal of Public Administration Research and Theory, 17(1), 95-117.

Weible, C., Sabatier, P., \& McQueen, K. (2009). Themes and variations: Taking stock of the advocacy coalition framework. Policy Studies Journal, 37(1), 121-141.

Weiss, C. H., \& Bucuvalas, M. J. (1977). The challenge of social research to decision making. Using social research in public policy making, 11, 213.

Yun, J. J., Won, D., \& Park, K. (2016). Dynamics from open innovation to evolutionary change. Journal of open innovation: Technology, market, and complexity, 2(1), 7.

Zahariadis, N., \& Allen, C. S. (1995). Ideas, networks, and policy streams: Privatization in Britain and Germany. Review of Policy Research, 14(1-2), 71-98.

\section{Mass media and public documents}

Park calls for passage of pension reform bill by year's end. (2014). Korea Times. Retrieved August 28, 2015, from http://koreatimes.co.kr/www/news/nation/2014/10/113_167096.html.

\section{Submit your manuscript to a SpringerOpen ${ }^{\circ}$ journal and benefit from:}

- Convenient online submission

- Rigorous peer review

- Open access: articles freely available online

- High visibility within the field

- Retaining the copyright to your article

Submit your next manuscript at $>$ springeropen.com 